\title{
Issues at the Rural-Urban Fringe: Hillsborough County Agriculture Stewardship Program 1
}

\section{Rodney L. Clouser and Stephen Gran²}

This publication is part of a series titled Issues at the Rural-Urban Fringe. The publications in this series can be found online at the EDIS website at http://edis.ifas.ufl.edu/ TOPIC_SERIES_Issues_at_the_Rural_Urban_Fringe.

\section{Introduction}

Florida's rapid population growth over the past three decades has called increased attention to conversion of agricultural land to non-agricultural use (development) by elected decision makers in government, agriculture producers, and citizens in general. States, counties, and cities are searching for programs that will maintain land in agricultural production both short and long term or at least prevent the premature conversion of agricultural land for development purposes. Many of the programs adopted to maintain land in agricultural use around the country center around frequently used programs such as use value assessment, fee simple purchase of lands, purchase of and transfer of development rights, purchase of agricultural conservation easements, etc. However, units of government around the country are adding their own unique twists to programs that will reduce or decelerate agricultural land conversion to non-agricultural uses.

\section{Hillsborough County}

Hillsborough County, Florida, surrounding Tampa Bay, is an example of a county concerned with the issue of agricultural land conversion and has adopted an "Agriculture Stewardship Program." Agriculture is important in Hillsborough County for many reasons, including the production of commodities for local, state, national, and international markets; income generated from the sale of locally produced commodities that infuses new spending and associated multiplier effects into the local area; employment of people; and wildlife habitat and open space. Population growth in Hillsborough County has been large and rapid. Population has increased from just over 490,000 residents in 1970 to almost 999,000 in 2000, and is projected to increase to almost 1.7 million by 2030 . The total cumulative growth in Hillsborough County over the 60-year period (1970-2030) will exceed 240 percent. Between 2000 and 2030, the county is projected to grow at a slightly higher rate than the state. Census Bureau population projections between 2000 and 2030 indicate that Hillsborough County will account for approximately six to seven percent of the state's growth over this 30-year time period.

1. This is EDIS document FE701, a publication of the Food and Resource Economics Department, Florida Cooperative Extension Service, Institute of Food and Agricultural Sciences, University of Florida, Gainesville, FL. Published November 2007. Please visit the EDIS website at http://edis.ifas.ufl.edu.

2. Rodney L. Clouser, Professor, Food and Resource Economics Department, Florida Cooperative Extension Service, Institute of Food and Agricultural Sciences, University of Florida, Gainesville, FL; and Stephen Gran, Manager, Agriculture Industry Development, Hillsborough County, Tampa, Florida

The Institute of Food and Agricultural Sciences (IFAS) is an Equal Opportunity Institution authorized to provide research, educational information and other services only to individuals and institutions that function with non-discrimination with respect to race, creed, color, religion, age, disability, sex, sexual orientation, marital status, national origin, political opinions or affiliations. U.S. Department of Agriculture, Cooperative Extension Service, University of Florida, IFAS, Florida A. \& M. University Cooperative Extension Program, and Boards of County Commissioners Cooperating. Larry Arrington, Dean 
Hillsborough County covers over 1,000 square miles of land mass and about 42.4 percent of that area is agricultural land. Hillsborough County has 2,969 farms (the second most of any county in the state), and county farms produce over $\$ 392$ million in total annual sales. The average farm size in the county is 96 acres. The county is a primary producer of three significant agricultural commodities in the state:

1. Plant City / Dover area produces 88 percent of the strawberries in Florida.

2. Hillsborough County produces 11 percent of tomatoes in Florida.

3. Hillsborough County accounts for 85 percent of the tropical fish produced in Florida.

\section{Hillsborough County Agriculture Stewardship Program Criteria}

In 2005, there were 7,347 agricultural parcels in Hillsborough County classified by the property appraiser under use value assessment. Initial applications for participation in the stewardship program were accepted between November 1, 2006 and December 15, 2006. A total of 410 parcels, or approximately six percent of eligible parcels, were under application for the program. To qualify for the agriculture stewardship program, the land parcel must be classified as agriculture by the property appraiser under Section 193.461 of the Florida Statutes (use value assessment law). The Hillsborough County program covers all forms of agricultural production and agricultural-related structures on the parcel of land, but does not cover any form of residential structures on the property. Additionally, calendar-year taxes for the prior year must have been paid in full. Applications for inclusion in the program are submitted to the Hillsborough County Economic Development Department - Agriculture and Industry Program. This department is charged with reviewing all applications to ensure they adhere to program criteria. Funding for the stewardship program is limited and currently $\$ 1$ million per year is available. Applications for the program are based on a first come, first served basis. If, and when, funds are exhausted for the county budget year, qualified applicants are placed on a waiting list for funding in future years if additional budget authority and appropriations are made available.

The Hillsborough County program is a modified easement program. The easement is referred to as an "agricultural use easement", and is a lease of, not a purchase of, an easement. The uniqueness of the Hillsborough County program is that the easement is for a specified time period of ten years and not in perpetuity. Participation in the program after verification of eligibility requires execution of an agreement between the parcel owner and Hillsborough County Government, subject to funds available and appropriated by the Hillsborough Board of County Commissioners. Parcels enrolled in the program are eligible for an annual grant, payable after March 31st of the prior year's property tax on the land and qualified structures. The amount of the grant to the parcel owner is determined by the county, and currently is established at 75 percent of county government ad valorem taxes paid in the previous calendar year. Other limitations on property use from participation in the program are contained within the stewardship program agreement presented in Appendix C.

\section{Removal of Land Parcel from the Stewardship Program or Termination of Agreement Conditions}

After the agreement is entered into by the landowner, it continues yearly until the end of the ten-year time period. However, land enrolled in the stewardship program can be removed from the program by the county for any of the following reasons:

- Land is diverted from agricultural to a nonagricultural use;

- The landowner makes a formal request for all or a portion of the land to be removed;

- All or a portion of the land ceases to remain classified as agricultural; or

- The Board of County Commissioners does not appropriate funds for the payment of grants under the program in any year during the term of the agreement. 
If Hillsborough County removes all or a portion of the land from the stewardship program prior to the expiration of the agreement, the landowner is subject to the following conditions:

- If all land is removed from the program because it has been diverted to a non-agricultural use, classification as agricultural land under Florida Statutes 193.461 is terminated or the landowner requests removal of all land from the program, the landowner shall be required to pay the county an amount established in a grant recapture payment schedule, applicable to all of the land, and the agreement, including the agricultural use easement, will be terminated. The grant recapture payment schedule is based on the number of years the parcel is enrolled in the stewardship program (Table 1).

Table 1. Grant recapture payment schedule.

\begin{tabular}{|ll|}
\hline \hline Years in Program & Grant Repayment Amount \\
\cline { 3 - 3 } After Year 1 & Repay 1 Year of Grant \\
After Year 3 & Repay 2 Years of Grant \\
After Year 4 & Repay 3 Years of Grant \\
After Year 5 & Repay 4 Years of Grant \\
After Year 6 & Repay 5 Years of Grant \\
After Year 7 & Repay 4 Years of Grant 3 Years of Grant \\
After Year 8 & Repay 2 Years of Grant \\
After Year 9 & Repay 1 Years of Grant \\
After Year 10 & Repay 0 Years of Grant \\
\hline \hline
\end{tabular}

- If all land is removed from the program because the Board of County Commissioners has not appropriated funds for the payment of grants in a program year, the landowner will not be subject to any grant recapture payment and the agreement, including the agricultural use easement, will be terminated.

- If a portion of the land is removed from the Program because the landowner requests removal or a portion ceases to remain classified as agricultural, future annual grant payments will be reduced accordingly. In addition, the landowner will be required to pay the county a pro-rated grant recapture payment applicable to the portion of the land removed from the program. The agreement, including the agricultural use easement, will be modified to reflect the portion of the land removed from the program.

- Any land remaining in the program must remain classified as agricultural, as determined by the County Property Appraiser.

\section{Other Stewardship Program Conditions}

Upon completion of the initial ten-year agreement and subject to continuation of the stewardship program through annual appropriations, the landowner has the option to remain enrolled in the program on a year-to-year basis. If the parcel owner decides to remove the land from the program any time after the initial agreement, there is no grant payment recapture provision.

A copy of the resolution establishing the program in Hillsborough County is contained in Appendix A. The application that must be completed to participate in the stewardship program is available in Appendix B. Finally, the agreement signed by the parcel owner upon acceptance in the county stewardship program is presented in Appendix C. A complete copy of the resolution, application, agreement, and other program conditions can be obtained from the Hillsborough County Economic Development Department - Agriculture and Industry Program.

\section{Concluding Comments}

The Hillsborough County Agriculture Stewardship Program is a modified easement lease. Upon qualifying and being accepted into the program, a lease agreement for an agriculture use easement is signed and is effective for ten years. However, lease of the easement is not binding for the land parcel owner. Land can be withdrawn from the agreement at any point in time, but based on the amount of time the land has be enrolled in the program a recapture payment of the grant is required. Full recapture is required for the first five years and a declining scale is in place after five years.

Landowners can continue in the program after the 
ten-year time period on a year-to-year basis, but no recapture of the grant occurs after ten years of enrollment.

The program does not guarantee that the best, or most desirable, or most developable land is enrolled in the program, since the program is operated on a first come, first served enrollment concept with limited funding. Maximum benefits accrue to landowners if they fulfill the entire ten-year agreement, but even after seven years, landowners receive a benefit equivalent to 75 percent of the ad valorem tax rate for four years (they must pay a three-year recapture fee).

A total of 410 parcels, covering 11,196 acres, were under application for the program in 2007. Applications for the program represent only a small percentage of the agricultural production acreage in Hillsborough County (about 7\%). Yet, without the program, there would be no acreage enrolled in the program. Will the program in Hillsborough County reduce the conversion of agricultural land or decelerate the premature conversion of land for development purpose? It is too early to tell, but over time the location of parcels enrolled in the program and the number of parcels withdrawn from the program will aid in this assessment.

The Hillsborough County Stewardship Program clearly can enroll parcels in the program at a fraction of the cost associated with other land maintenance programs. This trade-off is made possible by a time-specific lease agreement rather than a program based upon perpetuity.

\section{References}

Hillsborough County, Florida website. http://www.hillsboroughcounty.org/econdev/ agriculture/.

Hillsborough County, Florida website. http://www.hillsboroughcounty.org/econdev/ agriculture/facts.cfm.

Hillsborough County, Florida website. http://www.hillsboroughcounty.org/econdev/ resources/forms/agriculture/ stewardshipprogramapplication.pdf.
USDA, National Agricultural Statistics Service. 2002 CENSUS OF AGRICULTURE - Florida County Data.

Watson, Craig. University of Florida, Institute of Food and Agricultural Sciences Tropical Fish Lab. 
Appendix A. Hillsborough County Agriculture Stewardship Program Resolution

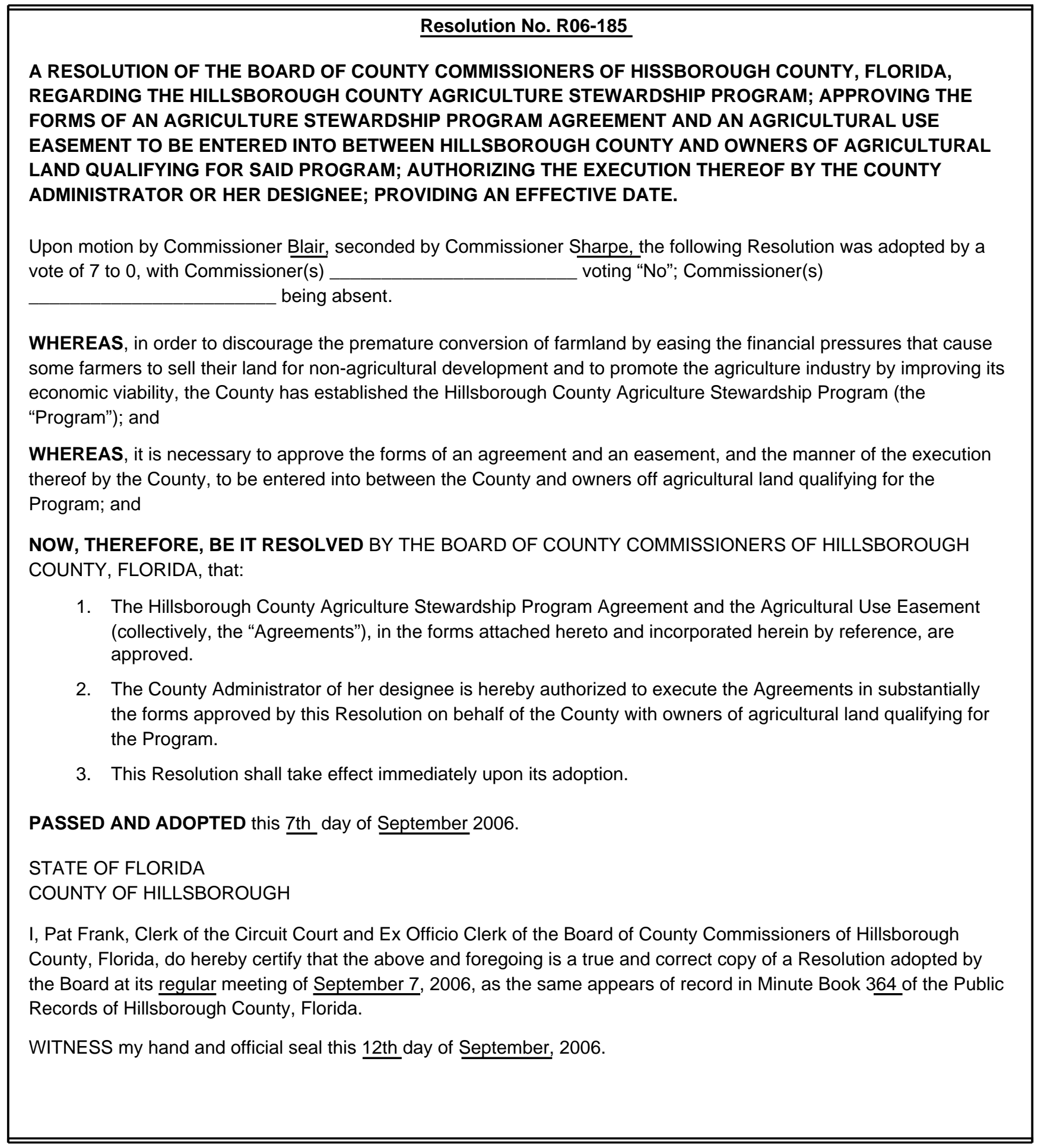


Appendix B. Application for Hillsborough Agriculture Stewardship Program

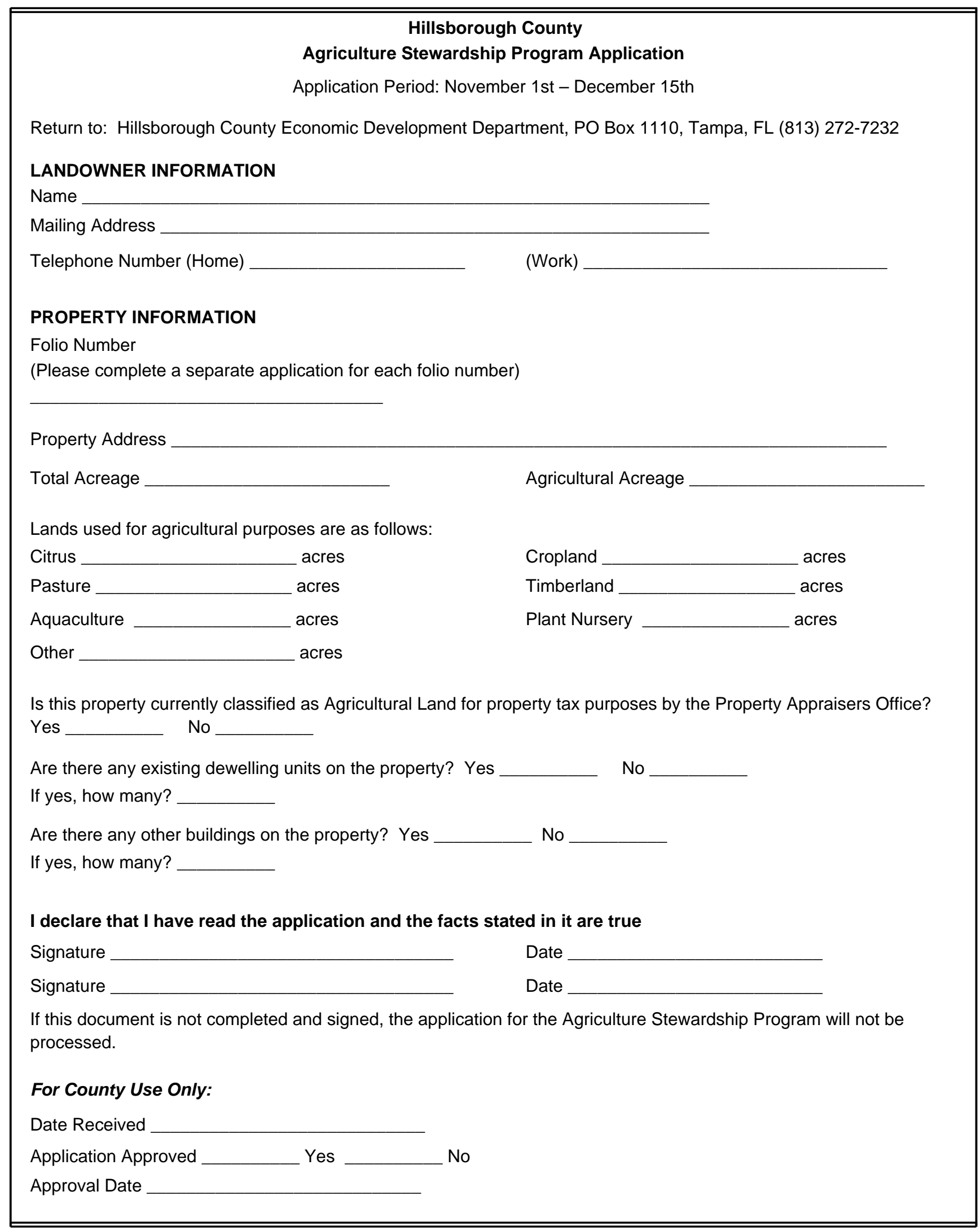


Appendix C. Hillsborough County Agriculture Stewardship Program Agreement

\section{AGRICULTURAL USE EASEMENT}

In consideration of the premises and mutual covenants, terms, conditions and restrictions contained herein and other good and valuable consideration, the receipt of which is hereby acknowledged, (the

"Grantor"), whose mailing address is

, the owner of the property described in Exhibit "A" (the "Property"), attached hereto and incorporated by this reference, hereby grants and gives to Hillsborough County, a political subdivision of the State of Florida (the "Grantee") whose mailing address is Post Office Box 1110, Tampa, Florida 33601, this Agricultural Use Easement over the whole of the Property of the Grantor, as of this day of , 20

It is the purpose and intent of this Agricultural Use Easement to assure that the Property will be retained and maintained for agricultural uses as defined in Section 193.461, Florida Statutes, or its successor in function (collectively "Agricultural Uses"). The Grantee by receipt and acceptance of this Agricultural Use Easement acknowledges and affirms that this Agricultural Use Easement is being received in consideration for the Agriculture Stewardship Grants to be received by the Grantor pursuant to the Hillsborough County Agriculture Stewardship Program Agreement between the Grantee and the Grantor.

The use of the Property is expressly limited by this Agricultural Use Easement as detailed herein, and variances pursuant to existing or future regulation contrary to the following limitations shall not be sought or granted, except when clearly in the public interest.

a) USE: The Property shall be used exclusively for Agricultural Uses.

b) CONSTRUCTION: No residential, commercial or industrial structures, roads, billboards, or other structure shall be placed above ground within the Property except existing structures on the Property and the only permitted additional structures are those that are directly associated with and necessary for Agricultural Uses.

c) EXCAVATION: There will be no dumping of any type of trash, debris, sludge, or other materials except those materials directly associated with and necessary for Agricultural Uses. There will be no topographical alteration, excavation, filling, or other earthmoving alteration of the Property except those actions directly associated with and necessary for Agricultural Uses.

d) SUBDIVISION: The Property will not be subdivided for conveyance of any portion to another party, or any change in use from an Agricultural Use, except for settlement of eminent domain under a settlement agreement authorized by both the Grantor and the Grantee.

It is understood that the granting of this Agricultural Use Easement entitles the Grantee or its authorized representatives to enter the Property in a reasonable manner and at reasonable times to assure compliance with the provisions of this Agricultural Use Easement.

The Grantor hereby agrees to bear all costs and liability relating to the operation and maintenance of the Property subject to this Agricultural Use Easement in the condition existing at the time of execution of this Agricultural Use Easement.

The Agricultural Use Easement hereby granted, and the obligation to retain and maintain the Property for Agricultural Uses as herein specified, shall run with the Property and shall be binding upon the Grantor, and shall inure to the benefit of the Grantee.

As used herein the term Grantor shall include any successor or assignee of the Grantor, and the term Grantee shall include any successor or assignee of the Grantee.

The terms and conditions of the Agricultural Use Easement may be enforced by the Grantee by injunctive relief and other appropriate available remedies, and the Grantor consents that venue for such enforcement actions shall lie exclusively in the Circuit Court of the Thirteenth Judicial Circuit, in Hillsborough County, Florida. Moreover, the Grantee shall be entitled to reasonable attorneys fees and costs from the Grantor in the event that such relief and remedies are necessary. 
Appendix C. Hillsborough County Agriculture Stewardship Program Agreement

IN WITNESS WHEREOF, the parties have executed this Agricultural Use Easement as of the day and year first above written.

Signed, sealed and delivered in the presence of:

WITNESSES:

By:

Print Name:

COUNTY OF

\section{"GRANTOR"}

By:

Print Name:

Title

Date:

The foregoing instrument was acknowledged before me this day of 20 , by $\mathrm{S} / \mathrm{He}$ is personally known to me or has produced as identification.

NOTARY PUBLIC:

Print Name:

Commission ID No.

\section{ATTEST:}

Pat Frank

Clerk of the Circuit Court

By:

Deputy Clerk

Approved as to Form and Legal Sufficiency

By:

Sr. Assistant County Attorney

\section{"GRANTEE"}

Hillsborough County, a political subdivision of the State of Florida

By:

Date: 